\title{
An inventory framework for inclusion of textile chemicals in life cycle assessment
}

\author{
Sandra Roos ${ }^{1,2}$ (1) $\cdot$ Christina Jönsson ${ }^{2} \cdot$ Stefan Posner $^{2} \cdot$ Rickard Arvidsson $^{1} \cdot$ Magdalena Svanström $^{1}$
}

Received: 27 February 2018 / Accepted: 2 October 2018 / Published online: 16 October 2018

(C) The Author(s) 2018

\begin{abstract}
Purpose Toxicity impacts of chemicals have only been covered to a minor extent in LCA studies of textile products. The two main reasons for this exclusion are (1) the lack of life cycle inventory (LCI) data on use and emissions of textile-related chemicals, and (2) the lack of life cycle impact assessment (LCIA) data for calculating impacts based on the LCI data. This paper addresses the first of these two.

Methods In order to facilitate the LCI analysis for LCA practitioners, an inventory framework was developed. The framework builds on a nomenclature for textile-related chemicals which was used to build up a generic chemical product inventory for use in LCA of textiles. In the chemical product inventory, each chemical product and its content was modelled to fit the subsequent LCIA step. This means that the content and subsequent emission data are time-integrated, including both original content and, when relevant, transformation products as well as impurities. Another key feature of the framework is the modelling of modularised process performance in terms of emissions to air and water.

Results and discussion The inventory framework follows the traditional structure of LCI databases to allow for use together with existing LCI and LCIA data. It contains LCI data sets for common textile processes (unit processes), including use and emissions of textile-related chemicals. The data sets can be used for screening LCA studies and/or, due to their modular structure, also modified. Modified data sets can be modelled from recipes of input chemicals, where the chemical product inventory provides LCA-compatible content and emission data. The data sets and the chemical product inventory can also be used as data collection templates in more detailed LCA studies.

Conclusions A parallel development of a nomenclature for and acquisition of LCI data resulted in the creation of a modularised inventory framework. The framework advances the LCA method to provide results that can guide towards reduced environmental impact from textile production, including also the toxicity impacts from textile chemicals.

Recommendations The framework can be used for guiding stakeholders of the textile sector in macro-level decisions regarding the effectiveness of different impact reduction interventions, as well as for guiding on-site decisions in textile manufacturing.
\end{abstract}

Keywords Chemical $\cdot$ LCA $\cdot$ Life cycle inventory $\cdot$ Textile $\cdot$ USEtox

Responsible editor: Ralph K. Rosenbaum

Electronic supplementary material The online version of this article (https://doi.org/10.1007/s11367-018-1537-6) contains supplementary material, which is available to authorized users.

Sandra Roos

sandra.roos@swerea.se

1 Division of Environmental Systems Analysis, Chalmers University of Technology, Vera Sandbergs Allé 8, 41296 Gothenburg, Sweden

2 Swerea IVF, Box 104, 43122 Mölndal, PO, Sweden

\section{Introduction}

The textile industry is one of the world's largest industry sectors. In 2014, the share of textiles and clothing in world merchandise trade was $4.3 \%$ (World Trade Organization 2015), and in 2016, the textile world market surpassed 100 million tonnes (The Fibre Year 2017). These figures give an indication of the potential magnitude of the environmental impacts of the textile sector, for which climate change, energy use, land use and water consumption are highly relevant environmental aspects (The Ellen MacArthur Foundation 2017). Another major environmental concern for the textile industry is the use of large amounts of chemicals in textile production 
processes and subsequent emissions of toxic substances (European Commission 2003; Munn 2011).

The focus of this paper is the inclusion of chemical products used in and chemical substances emitted from textile production processes - henceforth referred to as textile-related substances - in life cycle assessment (LCA). In general, when evaluating the environmental performance of products with LCA, it is important to include the impacts from chemicals (Hitchcock et al. 2012; Larsen et al. 2009; Laurent et al. 2012; Panko and Hitchcock 2011). However, for textile-related substances, the difficulties in obtaining life cycle inventory (LCI) data due to the complex textile manufacturing chains were noted already by Beck et al. (2000) and are still considered a problem (Terinte et al. 2014).

An overview of textile manufacturing processes is found in Fig. 1. A textile product may consist of several parts, for example lining, padding, shell and membrane. Most parts consist in turn of different fibres (cotton, polyester, wool, etc.) in different fabric constructions (weave, tricot, etc.). This implies that the textile production chain is diverse in terms of processes and equipment. Further, as different processes make use of different chemicals, the chemicals use and emissions are highly diverse as well. Today, the number of chemicals in use in the textile industry exceeds 15,000 - with over 10,000 dyes and pigments (SDC and AATCC 2016) and about 5000 auxiliary chemicals (TEGEWA 2016). Adding to the complexity, the chemicals used in processes (input chemicals) are not always the same as the chemicals emitted, since the latter can be (sometimes toxic) transformation products of the (sometimes non-toxic) input chemicals. The LCI analysis is further complicated by the fact that different process steps may be performed by different actors in different companies. The number of actors involved in one textile product may well exceed 50, with production sites spread across several continents (Kogg 2009).

LCA studies of textile products generally discuss and express concern regarding the emissions of toxic and persistent substances from textile production processes (e.g. Steinberger et al. 2009; Terinte et al. 2014). However, textile-related substances are seldom quantitatively included in the LCI (Roos 2015). When LCI data are missing for some inputs or emissions, the contribution to environmental impacts from these inputs or emissions will not be covered in the life cycle impact assessment (LCIA). A second reason for why textilerelated substances are excluded from the LCIA is the lack of characterisation factors to match the LCI data; a solution to this challenge is suggested by Roos et al. (2017) where a number of such characterisation factors are presented. Not including textile-related substances in LCA studies of textile products brings the risk of underestimating the total potential toxicity impacts of textile products, and important hotspots could potentially be missed. When toxicity impact potential results are reported for chemical-intensive textile processes (for example dyeing) without including textile-related substances, toxicity impacts are then related only to toxic emissions in the background processes (commonly exhaust gases from fuel combustion and leakage of substances from mining waste (Roos et al. 2015b)). A reader of such results may intuitively assume that emissions of textile-related substances are also included, especially when the exclusion is tacit.

The work with LCI of textile production can be very challenging, especially for LCA practitioners without a background in chemistry. Further, an LCA practitioner often enters the textile technology field as an external actor and not as an expert on textile technology, and meets a textile production chain that is highly diverse in materials, processes and equipment. The tacit exclusion of textile-related substances can thus at least partly be explained by the fact that the LCA practitioner is often neither a chemist nor a textile expert and therefore has difficulties identifying data gaps and gathering and understanding relevant chemical data. Also for chemistry experts, it is challenging that a 'chemical product' usually consists of a number of different substances, including - in addition to intentionally added substances - also residues from chemical production processes and/or impurities due to background contamination. Moreover, substances can be transformed by chemical reactions during the textile manufacturing process and/or by degradation in the environment and in organisms over time. Such transformation products, residues and impurities can often be of major environmental concern.

To support the work of LCA practitioners, an inventory framework for textile processes and textile-related substances

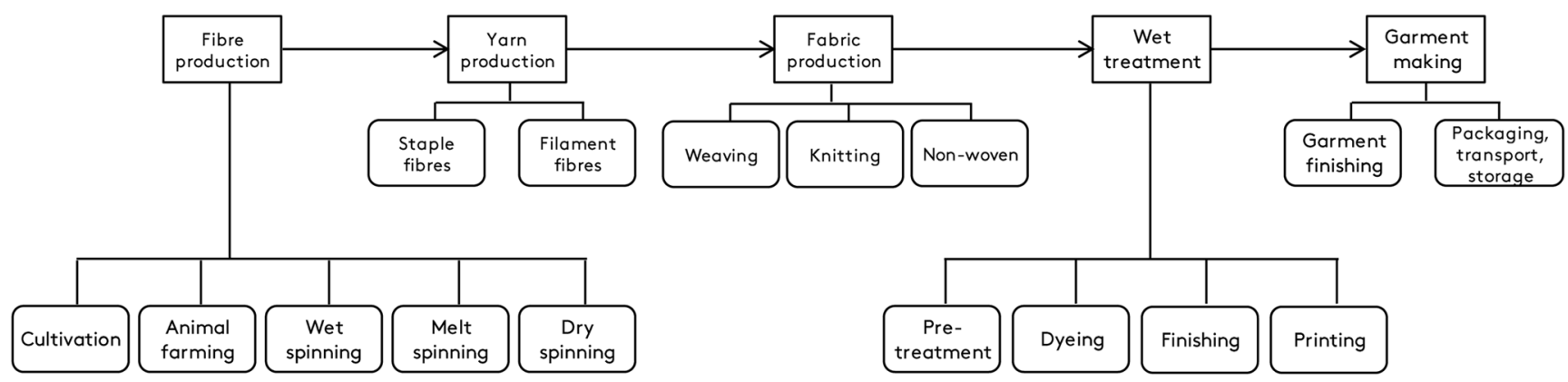

Fig. 1 Overview of textile manufacturing processes. The different processes make use of different chemical products and emit different chemical substances. Modified from Roos (2016), with permission 
was developed in this study. The framework consists of a nomenclature for textile-related chemicals (providing structure and terms) and LCI data. The emissions to air and water are modelled as independent modules so that the process performance can be varied (further explained in the Method and materials section). The nomenclature is based on functional properties of textile-related substances with terms recognised within the textile industry and therefore helps non-chemists and non-textile experts to inventory textile-related substances. LCI data for a number of relevant textile production processes were gathered and compiled in LCI data sets that fit the nomenclature. Together, these two parts (the nomenclature with its inherent terms and structure and the corresponding data sets) constitute an inventory framework, with the main purpose to enable and facilitate the inclusion of textile-related substances in LCA studies of textile products. This allows for toxicity impacts to be assessed in the LCA alongside other relevant impact categories, e.g. the ones mentioned above.

\section{Methods}

This section describes the development of the inventory framework for inclusion of textile-related substances in LCA of textile products. The conceptual model of the framework follows the structure of traditional LCI models such as in ecoinvent (Wernet et al. 2016), in order to be easily applied together with existing LCI and LCIA data. The framework was created through parallel and iterative development of nomenclature and LCI data.

\subsection{Data sources}

The data in the LCI data sets for textile production processes were partly collected from the literature and databases; a thorough literature review of available LCI data was reported in Roos et al. (2015a). Data were also collected in several independent case studies where the on-site data collection included input chemicals and related emissions in the textile life cycle. Such previously published studies were made: for textile chemicals in general (Olsson et al. 2009), for bamboo viscose tricot (Roos 2013), for lyocell weave (Roos 2012), and for cotton tricot (Roos and Posner 2011) and have been valuable data sources. Finally, complementary inventory analysis was performed within the Mistra Future Fashion project in order to compile a consistent whole. The inventory analysis included analysis of documents in the form of process set-up descriptions and safety data sheets, and dialogue with both the textile industry and the chemical industry about chemical formulations. All sources are specified in the Electronic Supplementary Material.

\subsection{Functional property-based nomenclature}

A nomenclature is needed to keep such LCI data modules consistent and to facilitate communication with all the actors in the textile value chain. The nomenclature was generated in an iterative manner during 10 years of close cooperation between the authors and the textile industry, as further detailed below. It is based on generic textile industry terms to facilitate communication between LCA practitioners and textile industry professionals in data collection and selection.

The origin of the nomenclature was the insight that communication about the chemical content of textile products is problematic for non-chemists (Swedish Chemicals Agency 2004), meaning persons without a higher education in chemistry. From 2005 and onwards, some of the authors of this paper have been engaged in a dialogue forum with the Nordic textile industry called the Swedish Chemicals Group (Swerea IVF 2016). This collaboration revealed that discussing relevant functional properties of the garment was more useful than discussing specific textile-related substances. With functional properties, we here mean the functions that a textile input chemical provides to the product, such as colour, soft hand or fire resistance (i.e. functional propertylending chemicals). The use of such a nomenclature has since been broadly applied within the Nordic textile industry, and this nomenclature has been formalised in tools such as the Swedish Chemicals Group's Chemicals Guide for chemical management (Posner et al. 2018). Thus, this nomenclature is already used in everyday supply chain dialogue, contracts, phase-out activities, educational activities, guidance documents, restricted substance lists (RSL) and other parts of the daily work of textile companies to comply with legal and customer requirements.

For this paper, the functional property concept has been expanded to include functions that textile-related substances can provide not only to finished garments but also during production processes, thus now including e.g. solvents, detergents and bleaching agents (i.e. process-related chemicals). The expansion of the nomenclature for process-related chemicals was also based on the chemicals' functional properties. The terms were obtained from documents such as the Chemicals Guide (Posner et al. 2018), the Textile Auxiliaries Buyers' Guide (TEGEWA 2008), the Colour Index ${ }^{\mathrm{TM}}$ database (SDC and AATCC 2016), the Reference Document on Best Available Techniques for the Textiles Industry (European Commission 2003) and directly during on-site data collection and in dialogue with representatives from the textile industry in the Swedish Chemicals Group.

The complete nomenclature thus consists of sub-sets of nomenclatures that are each already accepted and applied in their local context. They are here united to an entity covering the entire textile life cycle. In the nomenclature, impurities and transformation products that are known to be relevant from a 
toxicity perspective have been included (e.g. nonylphenol as a breakdown product from nonylphenol ethoxylates) to support the LCI data collection.

\subsection{Modularisation of $\mathrm{LCl}$ data sets}

The LCI data sets were created in a modularised form in order to enable LCA practitioners to create custom-made models of textile production chains and thereby account for the diversity of textile production processes. This deviates from the structure of most LCI databases that often contain aggregated data that cannot be custom-made or adapted to the particular circumstances of different studies. The LCI data sets were constructed based on the nomenclature and modularised to distinguish between the main process (where there is an input of chemicals) and associated emission control/waste management processes. Thus, the environmental performance of input chemicals and, for instance, waste water treatment are parameters that can be varied separately when using the framework (Fig. 2). The framework thus reflects that in some cases, materials and process steps may be identical from one supplier to another, whereas their waste management strategies may differ. The modular structure also gives flexibility regarding, for example, choice of energy source that can differ between geographic locations, and this can have a notable influence on toxicity impacts (Laurent and Espinosa 2015). Further, the pace at which LCI data become obsolete is also reduced when the parts can be updated separately.

\subsection{Scenarios}

The process performance regarding uptake of chemicals on the textile product and emissions of chemicals to air and water will in reality vary a lot and must be adapted to suit the study in question. Most processes have therefore been modelled at three levels with regard to process performance and input chemicals: best available technology (BAT), average and worst case. As an example, for the textile production process 'bleaching of cotton fabric', the input chemical used as bleach is the not-so-toxic hydrogen peroxide in the BAT scenario, the more toxic sodium chlorite in the average scenario and the even more toxic sodium hypochlorite in the worst-case scenario.

The process performance scenarios build on a number of general assumptions whereof some are varied in the BAT, average and worst case scenarios; see Table 1. All data sets are available in the Electronic Supplementary Material and in the 'Results and discussion' section; some examples are provided.

\subsubsection{Adaptation to match life cycle impact assessment}

LCI modelling of emissions and transformation products was conducted with the intention of subsequently calculating toxicity impact results with the USEtox model (Rosenbaum et al. 2008). A major implication of this adaptation to USEtox is that the model is time-integrated, which means that all emissions as well as transformation into degradation products in the environment is assumed to occur instantly (at time zero). Roos et al. (2017) provides calculated USEtox characterisation factors that match the LCI data presented here and describes the method behind the collection of the input data.

\section{Results and discussion}

\subsection{Chemical product inventory for LCA of textiles}

The chemical product inventory (sheet 36 in the Electronic Supplementary Material) contains in total 58 models of

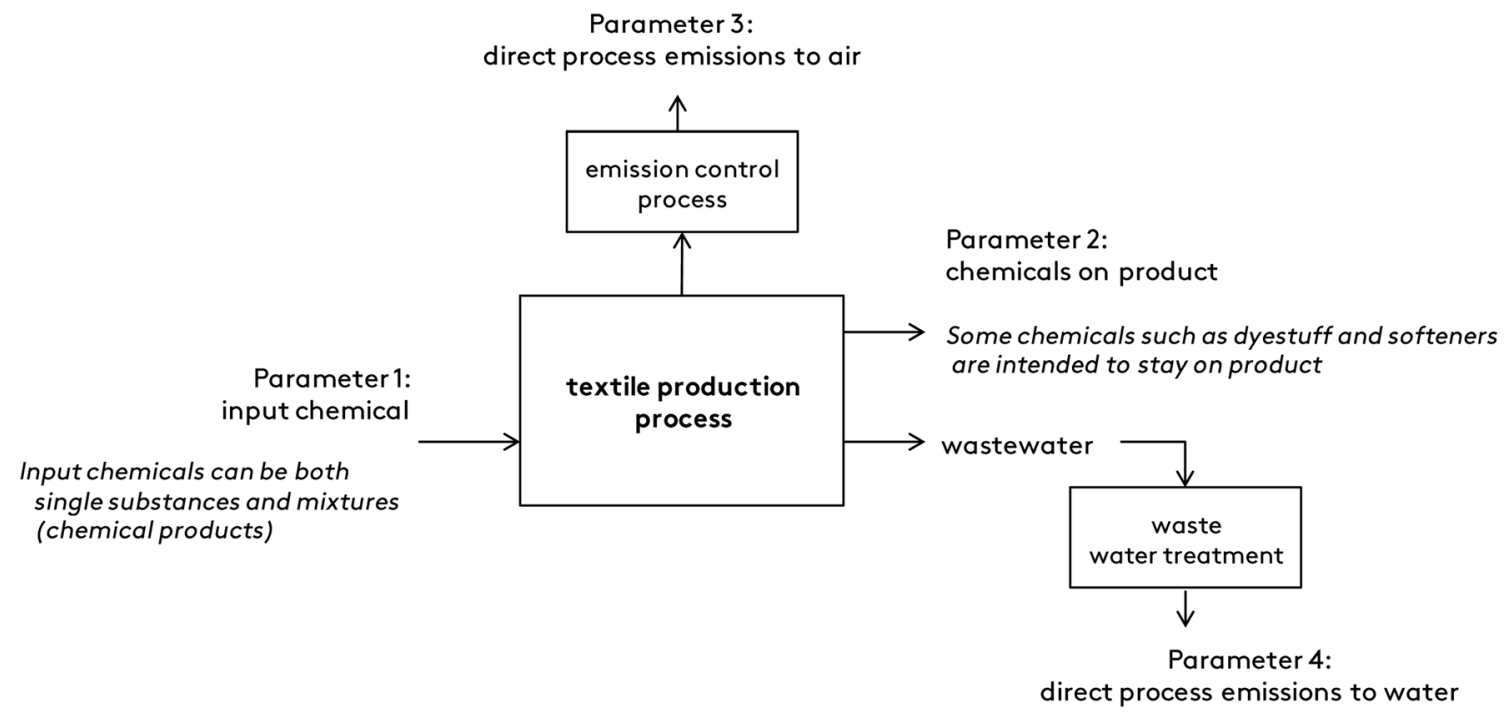

Fig. 2 The modularisation of LCI data sets. The four parameters can be varied separately 
Table 1 Assumptions applied in the process performance scenarios

\begin{tabular}{lc}
\hline Assumptions & Reference \\
\hline $\begin{array}{ll}\text { General assumption: } & \text { European } \\
\text { 95\% of } & \text { Commission } \\
\text { property-lending } & 2003 ; \text { Lacas } \\
\text { substances (dyes, } & \text { and Baum } \\
\text { durable water re- } & 2004^{3} \\
\text { pellents (DWR), } & \\
\text { softeners, etc.) } & \\
\text { will stay on the } & \\
\text { product } & \\
\text { General assumption: } & \text { Ash and Ash } \\
\text { 0.1\% of the } & 2004 \\
\text { content is } & \\
\text { degraded to } & \\
\text { common } & \\
\text { breakdown } & \\
\text { products } & \end{array}$
\end{tabular}

$\begin{array}{ll}\begin{array}{l}\text { of all volatile } \\ \text { compounds are }\end{array} & \begin{array}{c}\text { European } \\ \text { Commission }\end{array} \\ \text { emitted to urban } & 2003, \text { Annex } \\ \text { air after emission } & \text { IV } \\ \text { treatment: BAT } & \\ 0.01 \% \text {, average } & \\ 0.1 \% \text {, worst case } & \\ 1 \% & \\ \text { General assumption: } & \text { European } \\ 1 \% \text { of polymer } & \text { Commission } \\ \text { content remains as } & 2007 \\ \text { monomers from } & \\ \text { the production } & \\ \text { process } & \end{array}$

process

LCI data set parameter $\mathrm{s}$

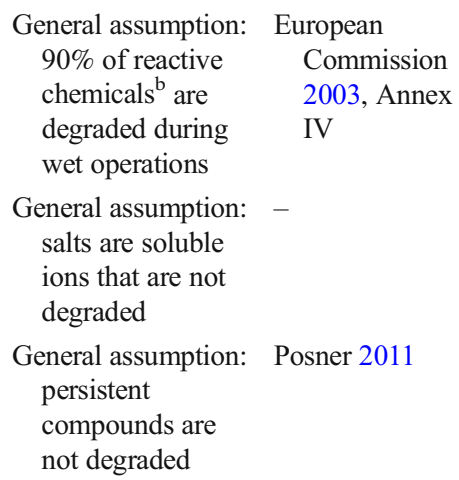
affected (from Fig. 2)

\section{Parameter 2 (chemicals on product): gives the value \\ Parameter 4 (direct process emissions to water): $0.05 *$ substance content will go to waste water treatment}

Parameter 1 (input chemical): gives the time-integrated content of chemical product (breakdown product content $=0.001 \times$ precursor content)

Parameter 3 (direct process emissions to air): yes if volatile substances

Parameter 4 (direct process emissions to water): breakdown product content $(=0.001 \times$ precursor content) will go to waste water treatment

Parameter 3 (direct process emissions to air): gives the value

Parameter 1 (input chemical): gives the time-integrated content of chemical product (breakdown product content $=0.001 \times$ precursor content)

Parameter 3 (direct process emissions to air): yes if volatile substances

Parameter 4 (direct process emissions to water): breakdown product content $(=0.001 \times$ precursor content) will go to waste water treatment

Parameter 4 (direct process emissions to water): for reactive chemicals only $0.1 \times$ substance content will go to waste water treatment

Parameter 4 (direct process emissions to water): $1.0 \times$ substance content will go to waste water treatment

Parameter 4 (direct process emissions to water): $1.0 \times$ the time-integrated content of chemical product
Table 1 (continued)

\begin{tabular}{|c|c|c|}
\hline Assumptions & Reference & $\begin{array}{l}\text { LCI data set parameter s } \\
\text { affected (from Fig. 2) }\end{array}$ \\
\hline & & $\begin{array}{l}\text { will go to waste water treat- } \\
\text { ment }\end{array}$ \\
\hline $\begin{array}{l}\text { General assumption: } \\
\text { dissociating } \\
\text { substances are } \\
\text { handled in the } \\
\text { LCIA }\end{array}$ & $\begin{array}{l}\text { Huijbregts et al. } \\
2015\end{array}$ & $\begin{array}{l}\text { None of the rules for } \\
\text { degradation are applied on } \\
\text { dissociating substances }\end{array}$ \\
\hline $\begin{array}{l}\% \text { of all chemicals } \\
\text { which are } \\
\text { removed in the } \\
\text { waste water } \\
\text { treatment process: } \\
\text { BAT } 99 \%, \\
\text { average } 90 \%, \\
\text { worst case } 0 \%\end{array}$ & $\begin{array}{l}\text { LeBlanc et al. } \\
2008\end{array}$ & $\begin{array}{l}\text { Parameter } 4 \text { (direct process } \\
\text { emissions to water): } \\
0.1 \times \text { the time-integrated } \\
\text { content of chemical product } \\
\text { will go to waste water treat- } \\
\text { ment }\end{array}$ \\
\hline
\end{tabular}

${ }^{\text {a }}$ For example, nonylphenol is released from nonylphenol ethoxylates. In some specific cases, deviations from this rule are made when real input values exist. For example, dimethylsilanediol is the primary hydrolysis product of polydimethylsiloxane, and in that case, $1 \%$ is instead assumed to be degraded (Griessbach and Lehmann 1999)

${ }^{\mathrm{b}}$ For example, hydrogen peroxide

input chemicals (Chemical product LCI in Fig. 3) that can be either a single substance or a mixture of substances. The nomenclature for textile-related substances consists of a list of generic categories of functions that an input chemical can have (Chemical function in Fig. 3), and the inventory also contains corresponding sets of emissions to air and water. For each of the generic categories of functions, a model of one or many representative input chemicals have been generated. For each input chemical, the chemical product inventory describes the time-integrated content (including impurities and transformation products) together with an average scenario for air and water emissions when used in textile processes.

Figure 3 illustrates that several chemical products can provide the same function, demonstrated for bleaching. Similarly, one chemical can be used in different chemical products thus providing different functions, demonstrated by hydrogen peroxide used in bleaching and/or as oxidising agent.

\section{$3.2 \mathrm{LCl}$ data sets}

The textile production processes for which LCI data sets have been created are shown in Fig. 4. These sets cover the most commonly occurring textile production processes, equipment and textile-related substances. They can for example be used for screening LCA studies that do not require highly specific results, and their general structure can also be used as data collection templates in more detailed LCA studies. The LCI data sets are unit process 
Fig. 3 Structure of the chemical product inventory. For each function, an inventory of BAT, average, and worst case chemical products that provide this function (bleach in the example) is available. Note that in the inventories of chemical products, the same substance can be part of several chemical products (e.g. both bleach and oxidising agents can contain hydrogen peroxide). Characterisation factors are collected either from the USEtox database, the COSMEDE database, or calculated with the USEtox model - these are published in Roos et al. (2017)

\begin{tabular}{l|l}
\hline \multicolumn{1}{|c|}{ Chemical function } \\
Accelerator \\
Acid \\
Antifoaming agent \\
Antireduction agent \\
Base \\
Bleach \\
Catalyst \\
Conducting salt \\
Decalcifier \\
Detergent \\
Dispergent \\
DWR agent \\
Dyestuff \\
Lubricant \\
Optical brightener \\
Oxidizing agent \\
$\begin{array}{l}\text {... } \\
\text { 27 functions }\end{array}$ \\
forwhich there are BAT, average \\
and worst case chemical products \\
that provides this function
\end{tabular}

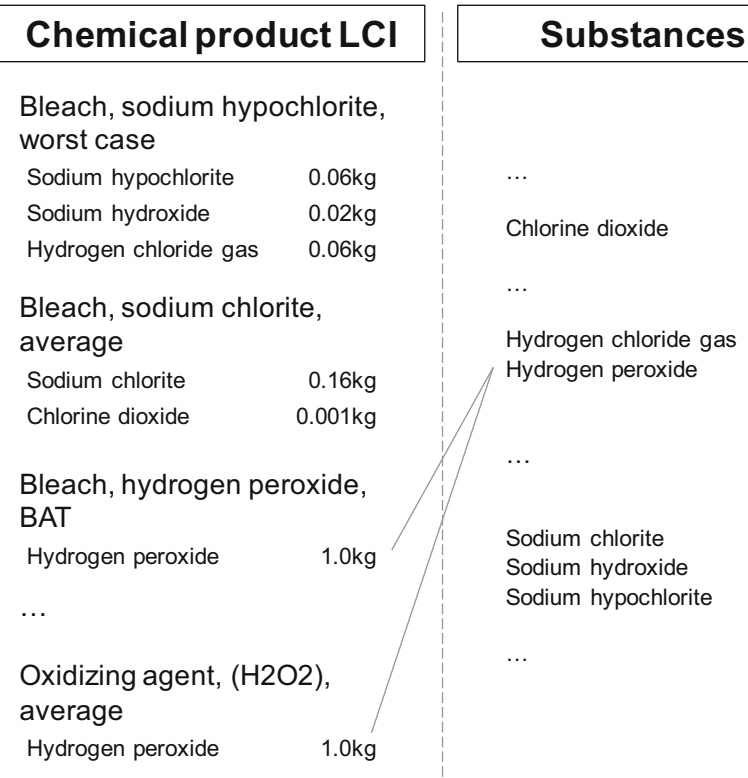

\section{8 chemical products} with emission scenarios to air and water

\section{2 substances}

with matching USEtox characterisation factors data sets, matching how data sets are formulated in e.g. the ecoinvent database (Wernet et al. 2016).

For all LCI data sets, textile input chemicals, and emissions to air and water of related substances, have been included based on the chemical product inventory (sheet 36 in the Electronic Supplementary Material). An example of an LCI data set (bleaching of cotton fabric, average data) is given in Table 2. Figure 5 illustrates the generic category of detergent function and shows how the substances in the input chemical products are modelled, including which breakdown products are expected in which output flows. Table 3 reports in detail how the emissions of textile input chemicals were modelled for that data set.

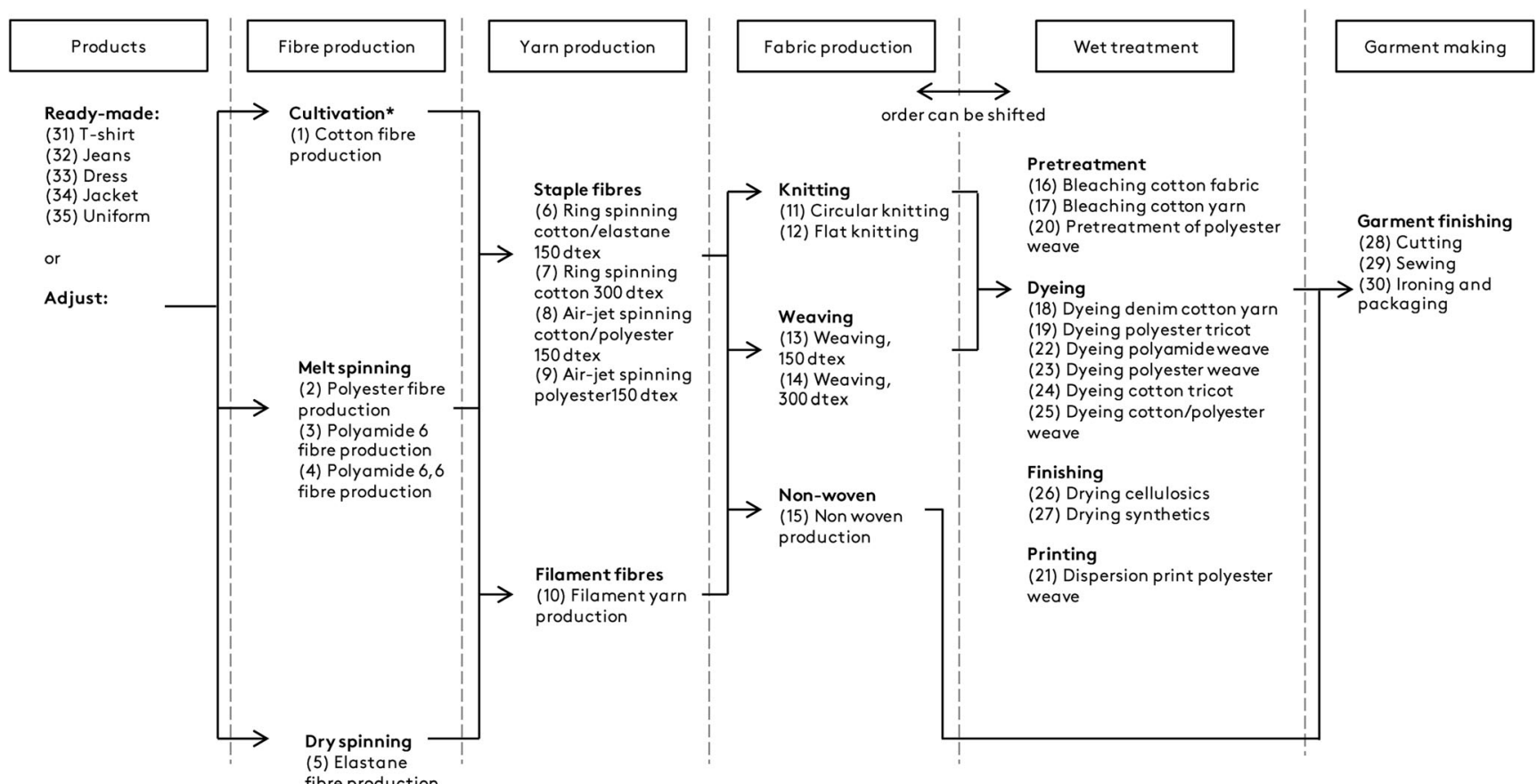

Fig. 4 Nomenclature for inventories of textile production processes, numbered 1-30. LCI data sets have been developed for these 30 processes. In addition, five archetype garments (31-35) have been modelled. All 35 data sets are found in the Electronic Supplementary Material. Asterisk indicates the cotton data set includes ginning and baling 
Table 2 Example of an LCI data set, for bleaching of cotton fabric, average data

\begin{tabular}{|c|c|c|}
\hline 16. Bleaching cotton tricot with optical brightener in jet machine, average (mix) & Amount & Unit \\
\hline \multicolumn{3}{|l|}{ Product } \\
\hline Bleached cotton fabric & 1 & $\mathrm{~kg}$ \\
\hline \multicolumn{3}{|l|}{ Resources } \\
\hline Water, river & 0.06 & $\mathrm{~m}^{3}$ \\
\hline \multicolumn{3}{|l|}{ Materials/fuels } \\
\hline Lubricant, average & 0.08 & $\mathrm{~kg}$ \\
\hline Detergent/wetting agent, average & 0.04 & $\mathrm{~kg}$ \\
\hline Acid (formic acid), average & 0.01 & $\mathrm{~kg}$ \\
\hline Peroxide stabiliser, average & 0.002 & $\mathrm{~kg}$ \\
\hline Base (alkali) $(\mathrm{NaOH})$, average & 0.025 & $\mathrm{~kg}$ \\
\hline Bleach $\left(\mathrm{H}_{2} \mathrm{O}_{2}\right)$, average & 0.07 & $\mathrm{~kg}$ \\
\hline Optical brightener, average & 0.06 & $\mathrm{~kg}$ \\
\hline Acid (sulphuric acid), average & 0.02 & $\mathrm{~kg}$ \\
\hline Softener, average & 0.03 & $\mathrm{~kg}$ \\
\hline Air emissions from $1 \mathrm{~kg}$ lubricant, average & 0.08 & $\mathrm{~kg}$ \\
\hline Air emissions from $1 \mathrm{~kg}$ detergent/wetting agent, average & 0.04 & $\mathrm{~kg}$ \\
\hline Air emissions from $1 \mathrm{~kg}$ acid (formic acid), average & 0.01 & $\mathrm{~kg}$ \\
\hline Air emissions from $1 \mathrm{~kg}$ peroxide stabiliser, average & 0.002 & $\mathrm{~kg}$ \\
\hline Air emissions from $1 \mathrm{~kg}$ bleach $\left(\mathrm{H}_{2} \mathrm{O}_{2}\right)$, average & 0.07 & $\mathrm{~kg}$ \\
\hline Air emissions from $1 \mathrm{~kg}$ acid (sulphuric acid), average & 0.02 & $\mathrm{~kg}$ \\
\hline Water emissions from $1 \mathrm{~kg}$ lubricant, average & 0.08 & $\mathrm{~kg}$ \\
\hline Water emissions from $1 \mathrm{~kg}$ detergent, average & 0.04 & $\mathrm{~kg}$ \\
\hline Water emissions from $1 \mathrm{~kg}$ acid (formic acid), average & 0.01 & $\mathrm{~kg}$ \\
\hline Water emissions from $1 \mathrm{~kg}$ peroxide stabiliser, average & 0.002 & $\mathrm{~kg}$ \\
\hline Water emissions from $1 \mathrm{~kg}$ base $(\mathrm{NaOH})$, average & 0.025 & $\mathrm{~kg}$ \\
\hline Water emissions from $1 \mathrm{~kg}$ bleach $\left(\mathrm{H}_{2} \mathrm{O}_{2}\right)$, average & 0.07 & $\mathrm{~kg}$ \\
\hline Water emissions from $1 \mathrm{~kg}$ optical brightener, average & 0.06 & $\mathrm{~kg}$ \\
\hline Water emissions from $1 \mathrm{~kg}$ acid (sulphuric acid), average & 0.02 & $\mathrm{~kg}$ \\
\hline Water emissions from $1 \mathrm{~kg}$ softener, average & 0.03 & $\mathrm{~kg}$ \\
\hline \multicolumn{3}{|l|}{ Electricity/heat } \\
\hline $\mathrm{MiFuFa}^{\mathrm{a}}$ electricity mix & 0.700 & $\mathrm{kWh}$ \\
\hline Heat, light fuel oil, at boiler $10 \mathrm{~kW}$, non-modulating/CH S & 8.333 & $\mathrm{kWh}$ \\
\hline \multicolumn{3}{|l|}{ Emissions to water } \\
\hline COD, chemical oxygen demand & 0.0002 & $\mathrm{~kg}$ \\
\hline \multicolumn{3}{|l|}{ Waste to treatment } \\
\hline $\begin{array}{l}\text { Disposal, sludge from pulp and paper production, } 25 \% \text { water, to sanitary landfill/CH } \\
\text { EcoInvent System }\end{array}$ & 0.5 & $\mathrm{~kg}$ \\
\hline
\end{tabular}

Please note that air and water emissions are models of the emitted substances per chemical product. The actual amounts per substance are specified in the chemical products inventory

${ }^{\mathrm{a}}$ Weighted electricity mix for a generic textile-exporting country, modelled as China (65\%), Bangladesh (23\%), and Turkey (12\%). See Roos et al. (2016) for further info
Finally, five archetype models of garments were constructed out of the LCI data sets: T-shirt, jeans, dress, jacket and uniform production (data sets 31-35, see Fig. 4). These archetype garments provide information on common combinations of the textile production processes in terms of materials, fabric construction, finishing processes, etc. to guide the LCA practitioner on how the data sets can be used.

\subsection{Recommendations, limitations and further work}

A parallel development of a nomenclature for and acquisition of LCI data resulted in the creation of a modularised inventory framework for LCA studies of textile products. The framework advances the LCA method to provide results that can guide towards reduced environmental impact from textile 


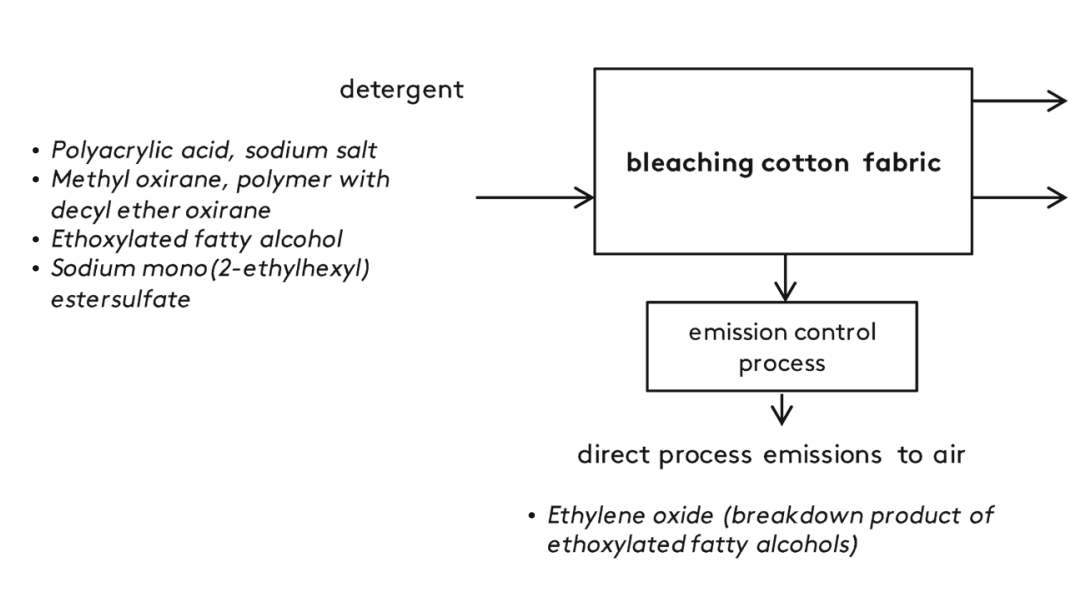

chemicals on product

detergent-related substances may residue in material as contamination but mostly dyestuff, softeners, optical brighteners etc. are intended to stay on product

wastewater

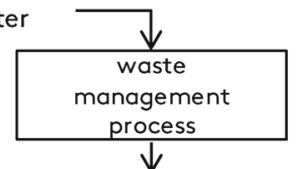

direct process emissions to water

- Polyacrylic acid, sodium salt

- Methyl oxirane, polymer with

decyl ether oxirane

- Ethoxylated fatty alcohol

- Sodium mono(2-ethylhexyl)estersulfate

- Formaldehyde (breakdown product of polyacrylic acid)

- Ethylene oxide (breakdown product of ethoxylated fattyalcohols)

Fig. 5 Model of the input chemical 'detergent' used in the process of bleaching cotton fabric (data set no. 16 from Fig. 4, average data). The example shows a process where the output chemicals differ partly from

production, including also the toxicity impacts from textile chemicals. The LCI data sets can be used for screening LCA studies and/or, due to their modular structure, also modified. Modified data sets can be modelled from recipes of input chemicals, where the chemical product inventory provides LCA-compatible content and emission data. The data sets the input chemicals. The same modelling is employed for all input chemicals (besides detergents, other chemicals are used in the bleaching of cotton fabric)

and the chemical product inventory can also be used as data collection templates in more detailed LCA studies.

The framework can be used for guiding stakeholders of the textile sector in macro-level decisions regarding the effectiveness of different impact reduction interventions, as well as for guiding on-site decisions in textile

Table 3 Details on how emissions are modelled for a process (No. 16 - bleaching of cotton fabric, average data) regarding the amount of used input chemicals and emissions

\begin{tabular}{|c|c|c|c|c|}
\hline Input chemical & Chemical substance & $\begin{array}{l}\text { Input chemical } \\
\text { content }(\mathrm{kg})\end{array}$ & $\begin{array}{l}\text { Air } \\
\text { emissions }(\mathrm{kg})\end{array}$ & $\begin{array}{l}\text { Water } \\
\text { emissions }(\mathrm{kg})\end{array}$ \\
\hline Lubricant, average & Acrylamide/sodium acrylate copolymer & 0.3 & $2.0 \mathrm{E}-04$ & $2.0 \mathrm{E}-02$ \\
\hline Lubricant, average & Acrylamide & $\mathrm{BP}^{*}$ & $1.0 \mathrm{E}-04$ & $1.0 \mathrm{E}-02$ \\
\hline Detergent, average & Polyacrylic acid, sodium salt & 0.1 & - & $1.0 \mathrm{E}-02$ \\
\hline Detergent, average & Methyl oxirane, polymer with decyl ether oxirane & 0.25 & - & $2.5 \mathrm{E}-02$ \\
\hline Detergent, average & Ethoxylated fatty alcohol & 0.1 & - & $1.0 \mathrm{E}-02$ \\
\hline Detergent, average & Sodium mono(2-ethylhexyl)estersulfate & 0.05 & - & $5.0 \mathrm{E}-03$ \\
\hline Detergent, average & Ethylene oxide & $I^{* * *}$ & - & $1.0 \mathrm{E}-04$ \\
\hline Detergent, average & Formaldehyde & $\mathrm{BP}^{*}$ & $1.0 \mathrm{E}-05$ & $1.0 \mathrm{E}-04$ \\
\hline Acid, formic acid & Formic acid & 1.0 & $1.0 \mathrm{E}-03$ & $1.0 \mathrm{E}-01$ \\
\hline Peroxide stabiliser, average & Polyacrylic acid, sodium salt & 0.10 & - & $1.0 \mathrm{E}-02$ \\
\hline Peroxide stabiliser, average & Phosphonic acid, disodium salt & 0.10 & - & $1.0 \mathrm{E}-02$ \\
\hline Peroxide stabiliser, average & Magnesium chloride & 0.005 & $5.0 \mathrm{E}-06$ & $5.0 \mathrm{E}-04$ \\
\hline Peroxide stabiliser, average & Formaldehyde & $\mathrm{BP}$ & - & $1.0 \mathrm{E}-04$ \\
\hline Base (alkali), average & Sodium hydroxide & 1.0 & - & $1.0 \mathrm{E}-01$ \\
\hline Bleach, BAT & Hydrogen peroxide & 1.0 & $1.0 \mathrm{E}-03$ & $1.0 \mathrm{E}-01$ \\
\hline Optical brightener, average & Stilbene disulphonic acid & 1.0 & - & $1.0 \mathrm{E}-01$ \\
\hline Acid, average & Sulphuric acid & 1.0 & $1.0 \mathrm{E}-03$ & $1.0 \mathrm{E}-01$ \\
\hline Softener, average & Octadecanoic acid & 0.2 & - & $2.0 \mathrm{E}-02$ \\
\hline Softener, average & Diethanolamine & 0.03 & - & $3.0 \mathrm{E}-03$ \\
\hline
\end{tabular}

$B P$ breakdown product, $I$ impurity 
manufacturing. It is also possible to use the approach described here, with a functional property-based nomenclature, a chemical product inventory and model LCI data sets, for other industry sectors where chemicals are of high concern.

Limitations include the lack of completeness of the current version of the chemical product inventory and the LCI data sets. There is, among other things, a lack of representative proxies for many textile processes (for example other fibres such as wool and silk or other printing techniques). The textile sector is under constant development, and neither textile processes nor chemical products in use are static. Hence, future data will need to be incorporated using the flexibility of the model. A further limitation lays in the dependence on LCIA characterisation factors that might need to be calculated if the chemical product inventory should be extended.

The framework needs to be tested in case studies to demonstrate its applicability, and to which extent, the results differentiate between processes but nonetheless provide an appropriate score. Following the LCA tradition with proxies based on model LCI data sets in databases, functional representation of chemicals using a nomenclature is a simplified way forward towards including chemicals in LCA studies of textile products.

\section{Conclusions}

The overarching purpose of this paper has been to promote more comprehensive LCA studies of textile products, where textile-related substances and their toxicity impacts are included alongside other relevant environmental impacts related to textiles, like climate change, energy use, land use and water use. LCI of textile production can be very challenging, especially for LCA practitioners that are non-chemists and nontextile experts. To support LCA practitioners, an inventory framework was developed, consisting of a functional property-based nomenclature (providing structure and terminology) as well as corresponding LCI data sets for common textile-related substances and processes. The LCI data sets can be used e.g. for screening LCA studies and as data collection templates in more detailed LCA studies. The framework can be used to generate LCA results that can serve as support for both consumers in making more informed environmentally conscious choices and for producers in their work to reduce toxicity impacts from their processes.

Funding information The researchers were supported by the Swedish Foundation for Strategic Environmental Research (Mistra) via the Mistra Future Fashion programme and the Swedish Research Council for Environment, Agricultural Sciences and Spatial Planning (Formas) via the SUPFES project (216-2012-2148) and initiative for excellence in production - XPRES.
Open Access This article is distributed under the terms of the Creative Commons Attribution 4.0 International License (http:// creativecommons.org/licenses/by/4.0/), which permits unrestricted use, distribution, and reproduction in any medium, provided you give appropriate credit to the original author(s) and the source, provide a link to the Creative Commons license, and indicate if changes were made.

\section{References}

Ash M, Ash I (2004) Handbook of Green Chemicals, 2nd ed. Endicott, NY : Synapse Information Resources, New York

Beck A, Scheringer M, Hungerbühler K (2000) Fate modelling within LCA: the case of textile chemicals. Int J Life Cycle Assess 5:335-344

European Commission (2007) Reference document on best available techniques in the production of polymers. Seville

European Commission (2003) Integrated pollution prevention and control (IPPC) reference document on best available techniques for the textiles industry. In: European IPPC Bureau, Seville

Griessbach EFC, Lehmann RG (1999) Degradation of polydimethylsiloxane fluids. Chemosphere 38:1461-1468

Hitchcock K, Panko J, Scott P (2012) Incorporating chemical footprint reporting into social responsibility reporting. Integr Environ Assess Manag 8:386-388

Huijbregts MAJ, Margni M, Hauschild MZ, Jolliet O, McKone TE, Rosenbaum RK, Van De Meent D (2015) USEtox® 2.0 user manual, 2nd ed. USEtox ${ }^{\circledR}$ team, Lyngby, Denmark

Kogg B (2009) Responsibility in the supply chain interorganisational management of environmental and social aspects in the supply chain case studies from the textile sector. IIIEE, Lund University, Lund

Lacasse K, Baumann W (2004) Textile chemicals - environmental data and facts. In: Springer-Verlag, Dortmund

Larsen HF, Hansen MS, Hauschild MZ (2009) Life cycle assessment of offset printed matter with EDIP97: how important are emissions of chemicals? J Clean Prod 17:115-128

Laurent A, Espinosa N (2015) Environmental impacts of electricity generation at global, regional and national scales in 1980-2011: what can we learn for future energy planning? Energy Environ Sci 8:689-701

Laurent A, Olsen SI, Hauschild MZ (2012) Limitations of carbon footprint as indicator of environmental sustainability. Environ Sci Technol 46:4100-4108

LeBlanc RJ, Matthews P, Richard RP (2008) Global atlas of excreta, wastewater sludge, and biosolids management: moving forward the sustainable and welcome use of a global resource. Nairobi

Munn K (2011) The Chemicals in Products Project : case study of the textiles sector, Geneva

Olsson E, Posner S, Roos S, Wilson K (2009) Kartläggning av kemikalieanvändning i kläder. Mölndal

Panko J, Hitchcock K (2011) Chemical footprint ensuring product sustainability. Air Waste Manag Assoc :12-15

Posner S (2011) Polyfluorinated chemicals and transformation products. In: Knepper TP (ed) Handbook of environmental chemistry. Springer, Heidelberg

Posner S, Olsson E, Roos S, Jönsson C, Fransson K (2018) Chemicals guidance. Information on authorization and restrictions of substances used in textile and leather processes and products. Edition: January, Gothenburg, p 2018

Roos S (2016) Advancing life cycle assessment of textile products to include textile chemicals. Inventory data and toxicity impact assessment. In: Chalmers University of Technology

Roos S (2015) Towards sustainable use of chemicals in the textile industry: how life cycle assessment can contribute. Chalmers University of Technology, Gothenburg 
Roos S (2013) Livscykelanalys av kläder av Life Wear® bamboo (publik version), Mölndal

Roos S (2012) Livscykelanalys av Tencelfiber. Swerea IVF Report 23497, Swerea IVF AB, Mölndal, Sweden

Roos S, Holmquist H, Jönsson C, Arvidsson R (2017) USEtox characterisation factors for textile chemicals based on a transparent data source selection strategy. Int J Life Cycle Assess 23:890-903

Roos S, Posner S (2011) Rekommendationer för hållbar upphandling av textilier. Stockholms Läns Landsting (SLL), Mölndal

Roos S, Posner S, Jönsson C, Peters GMGM, Jönsson C, Peters GMGM (2015a) Is unbleached cotton better than bleached? Exploring the limits of life cycle assessment in the textile sector. Cloth Text Res J 33:231-247

Roos S, Sandin G, Zamani B, Peters GM (2015b) Environmental assessment of Swedish fashion consumption. Five garments - sustainable futures. In: Mistra future fashion. Sweden, Stockholm

Roos S, Zamani B, Sandin G, Peters GM, Svanström M (2016) A life cycle assessment (LCA)-based approach to guiding an industry sector towards sustainability: the case of the Swedish apparel sector. J Clean Prod 133:691-700

Rosenbaum RK, Bachmann TM, Gold LS, Huijbregts MAJ, Jolliet O, Juraske R, Koehler A, Larsen HF, MacLeod M, Margni M, McKone TE, Payet J, Schuhmacher M, Meent D, Hauschild MZ (2008) USEtox - the UNEP-SETAC toxicity model: recommended characterisation factors for human toxicity and freshwater ecotoxicity in life cycle impact assessment. Int J Life Cycle Assess 13:532-546
SDC \& AATCC (2016) Colour Index [WWW Document]. Soc. Dye. Colour. AATCC. URL http://www.colour-index.com/ (accessed 6.2.16)

Steinberger JK, Friot D, Jolliet O, Erkman S (2009) A spatially explicit life cycle inventory of the global textile chain. Int J Life Cycle Assess 14:443-455

Swedish Chemicals Agency (2004) KemI Rapport 6/04 -information om varors innehåll av farliga kemiska ämnen, Sundbyberg

Swerea IVF (2016) Kemikaliegruppen, the Swedish chemicals group [WWW document]. URL www.kemikaliegruppen.se (accessed 10.26.15)

TEGEWA (2016) THK-online [WWW document]. URL http://www.thkonline.net/ (accessed 5.25.16)

TEGEWA (2008) TEGEWA's international textile auxiliaries Buyer's guide 2008/09. Deutscher Fachverlag GmbH, Frankfurt am Main

Terinte N, Manda BMK, Taylor J, Schuster KC, Patel MK (2014) Environmental assessment of coloured fabrics and opportunities for value creation: spin-dyeing versus conventional dyeing of modal fabrics. J Clean Prod 72:127-138

The Ellen MacArthur Foundation (2017) A new textiles economy: redesigning fashion's future

The Fiber Year (2017) The Fiber year. World Survey on Textile \& Nonwovens, Speicher, p 2017

Wernet G, Bauer C, Steubing B, Reinhard J, Moreno-Ruiz E, Weidema B (2016) The ecoinvent database version 3 (part I): overview and methodology. Int J Life Cycle Assess 21:1218-1230

World Trade Organization (2015) International trade statistics 2015. Switzerland, Geneva 